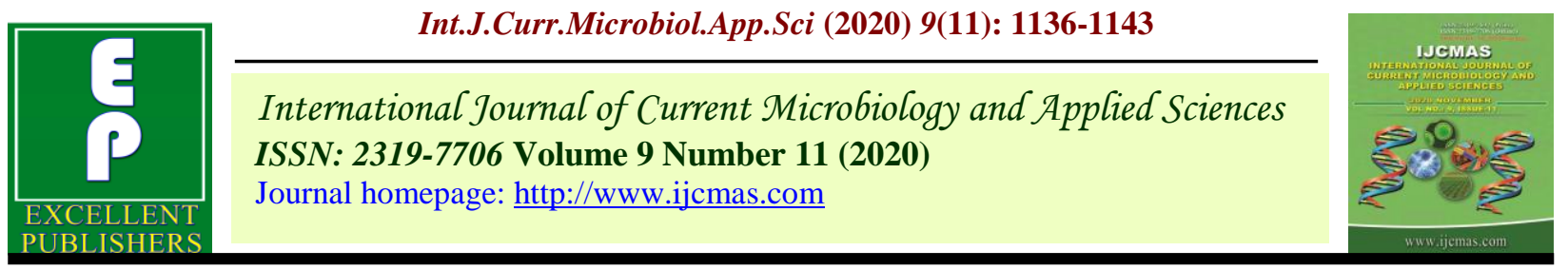

\title{
Effect of Plant Growth Regulators and Micronutrients on Vegetative and Flowering Characters of Gladiolus (Gladiolus grandiflorus L.) cv. Novalux
}

\author{
Abhinav Kumar* and Arun Kumar Singh \\ Department of Floriculture \& Landscape, Collage of Horticulture \& Forestry, Acharya \\ Narendra Deva University of Agriculture \& Technology, Ayodhya-224229 (U.P.) India \\ *Corresponding author
}

\section{A B S T R A C T}

\begin{tabular}{|l|}
\hline Key w o r d s \\
$\begin{array}{l}\text { Gladiolus, Novalux, } \\
\text { Vegetative growth } \\
\text { and Flowering } \\
\text { character's }\end{array}$ \\
\hline Article Info \\
\hline $\begin{array}{l}\text { Accepted: } \\
10 \text { October } 2020 \\
\text { Available Online: } \\
\text { 10 November } 2020\end{array}$ \\
\hline
\end{tabular}

\begin{abstract}
To work out the effect of plant growth regulators and micronutrients on vegetative growth and flowering characters of gladiolus (Gladiolus grandiflorus L.) cv. Novalux, The experiment was conducted in Factorial Randomized Block Design with 12 treatments replicated thrice at the Main Experiment Station, Department of Floriculture \&Landscape, Acharya Narendra Deva University of Agriculture \& Technology, Narendra Nagar (Kumarganj), Ayodhya (U.P.) during winter season in the year 2017-18 and 2018-19. The plant growth regulators and micronutrients application significantly influenced the growth and flowering attributes of gladiolus. The plant growth regulators significantly affects the days taken for complete sprouting of gladiolus. The earliest sprouting of corm, initiation of spike was found with Cycocel $500 \mathrm{ppm}$. The maximum plant height was noted in $\mathrm{GA}_{3} 200$ ppm with $\mathrm{ZnSO} 4$ 0.5\% + FeSO4 0.2\%.The maximum number of leaves, Length of spike and number of spikes per hectare was obtained with the combinations of CCC $500 \mathrm{ppm}$ with $\mathrm{ZnSO}_{4} 0.5 \%+\mathrm{FeSO}_{4} 0.2 \%$.
\end{abstract}

\section{Introduction}

The modern gladiolus hybrids are botanically known as Gladiolus grandiflorus. Gladiolus is one of the important monocotyledonous flowering perennial bulbous plant belongs to family Iridaceae and widely grown as a cut flower in the world and referred to as the "Queen of Bulbous" flowers. It has basic chromosome number $\mathrm{n}=15$ and majority of South African species are diploid $(2 \mathrm{n}=30)$.

The control over flowering time and floral characteristics according to the demand of market has been achieved in many cut flowers by adopting modern production techniques including the use of plant growth regulators (PGRs). The application of plant growth retardants has become the part of their cultural practices in many ornamental plants to modify their vegetative and floral traits.

$\mathrm{GA}_{3}$ delays senescence of flowers by reducing the senescence-promoting effect of ethylene. The application of $\mathrm{GA}_{3}$ was found to shorten number of days to flowering, increase spike length, number of flowers per spike, floret diameter, shoot elongation and vegetative growth significantly. Cycocel (Chlormequat chloride, 2-chloroethyl 
trimethyl ammonium chloride) is a plant growth regulator for ornamentals, including bedding plants and herbaceous crops. Cycocel enhances the crop's aesthetic appeal and improves durability during post production shipping and handling. Cycocel is a gibberellin inhibitor. Cycocel produces earlier budded plants with multiple buds per shoot.Cycocel can be used to reduce stem elongation induction of seed germination, Enzyme production during germination CCC is required for cell division and cell elongation.

Micronutrients such as zinc is an essential element for plants which acts as a cofactor of various enzymes or as a functional structural or regulatory component of various biosynthesis like protein synthesis, photosynthesis, the synthesis of auxin, cell division, the maintenance of membrane structure RNA and ribosome functions and sexual fertilization.

The micronutrients are responsible in activating several enzymes (catalase, peroxidase, alcohol dehydrogenase, carbonic dehydrogenase, etc.) and involve them self in chlorophyll synthesis and various physiological activities by which plant growth and development are encouraged (Kumar and Arora, 2000), Zinc also controls the metabolism of plant by stimulating the hydrogenase and carbonic anhydrase activities, stabilization of ribosomal fractions and synthesis of cytochrome.

There are evidences that iron deficiency impairs many plant physiological processes because it is involved in chlorophyll and protein synthesis and in root tip meristem growth. Tagliavini and Rombola (2001) illustrated that iron deficiency (chlorosis) is a common disorder which affect plants. Grown on soils of high $\mathrm{pH}$. Iron application through foliar spray is a common practice to cure irondeficiency (Mortvedt, 1991).

\section{Materials and Methods}

The experiment was laid out in Factorial Randomized Block Design (FRBD) with three replications and twelve treatments at Main Experimental Station, Horticulture, Acharya Narendra Deva University of Agriculture \& Technology, Kumarganj, Ayodhya during the year 2017-18 and 2018-19. The treatments are $\mathrm{G}_{1} \mathrm{M}_{1}$ (water dipping + water spray), $\mathrm{G}_{1} \mathrm{M}_{2}$ (water dipping $+\mathrm{ZnSO}_{4} 0.5 \%$ ), $\mathrm{G}_{1} \mathrm{M}_{3}$ (water dipping $+\mathrm{FeSO}_{4} 0.2 \%$ ), $\mathrm{G}_{1} \mathrm{M}_{4}$ (water dipping $\left.+\mathrm{ZnSO}_{4} 0.5 \%+\mathrm{FeSO}_{4} 0.2 \%\right), \mathrm{G}_{2} \mathrm{M}_{1}\left(\mathrm{GA}_{3}\right.$ $200 \mathrm{ppm}+$ water spray), $\mathrm{G}_{2} \mathrm{M}_{2}\left(\mathrm{GA}_{3} 200 \mathrm{ppm}\right.$ $\left.+\mathrm{ZnSO}_{4} 0.5 \%\right), \mathrm{G}_{2} \mathrm{M}_{3}\left(\mathrm{GA}_{3} 200 \mathrm{ppm}+\right.$ $\left.\mathrm{FeSO}_{4} 0.2 \%\right), \mathrm{G}_{2} \mathrm{M}_{4}\left(\mathrm{GA}_{3} 200 \mathrm{ppm}+\mathrm{ZnSO}_{4}\right.$ $\left.0.5 \%+\mathrm{FeSO}_{4} 0.2 \%\right), \mathrm{G}_{3} \mathrm{M}_{1}(\mathrm{CCC} 500 \mathrm{ppm}+$ water spray), $\mathrm{G}_{3} \mathrm{M}_{2}\left(\mathrm{CCC} 500 \mathrm{ppm}+\mathrm{ZnSO}_{4}\right.$ $0.5 \%), \mathrm{G}_{3} \mathrm{M}_{3}\left(\mathrm{CCC} 500 \mathrm{ppm}+\mathrm{FeSO}_{4} 0.2 \%\right)$ and $\mathrm{G}_{3} \mathrm{M}_{4}\left(\mathrm{CCC} 500 \mathrm{ppm}+\mathrm{ZnSO}_{4} 0.5 \%+\right.$ $\mathrm{FeSO}_{4} 0.2 \%$ ).

The field are prepared by well-decomposed farmyard manure was applied before land preparation at the rate of $25 \mathrm{t} / \mathrm{ha}$ and mixed well in to soil. Fertilizers were applied at the rate of $300: 200: 200 \mathrm{~kg} \mathrm{NPK} / \mathrm{ha} .50 \%$ of nitrogen and full dose of phosphorous and potash were applied as basal dose and remaining $50 \%$ of nitrogen was applied at 45 days after planting. Before planting, corms were dipped in prepared $\mathrm{GA}_{3} 200 \mathrm{ppm}$ solution for 1 hours and CCC 500 ppm solution for 24 hours after that dried under shade. Planting was done at $40 \times 20 \mathrm{~cm}$ spacing to a depth of $5-6 \mathrm{~cm}$ in plots of $2.0 \times 1.0 \mathrm{~m}$ size. The irrigation and weeding were done as and where required. The observation was recorded for the character viz. day to complete sprouting, height of plants in $\mathrm{cm}$, number of leaves par plant, days to initiation of spike, length of spike in $\mathrm{cm}$ and number of spikes per hectare. The obtained data had statistically analysed adopting procedure as given by Panse and Sukhatme (1985). 


\section{Results and Discussion}

The effect of plant growth regulators and micronutrients on various characters are presented in Table 1. Theplant growth regulator significantly affects the days taken for complete sprouting of gladiolus. The minimum number of days taken to complete sprouting of corm was found with Cycocel $500 \mathrm{ppm}$ (27.50 days and 28.83 days) during 2017-18 and 2018-19.

The effect of micronutrients was found nonsignificant as the micronutrients were applied 30 DAS of corm planting. The interaction effect of plant growth regulator and micronutrients was found non-significant during both the year of investigation (2017-18 and 2018-19).The early sprouting due to the plant growth regulators are known to coordinate and control various phases of plant growth and development.

The chemical regulation of plants by plant growth regulators are made possible through their influence on various enzyme systems, respiration and other metabolic activities. The major role of plant growth regulators in ornamental crops are regulation of flowering and prolonging the shelf life of flower.

Pre-soaking the seeds and bulbs/corms of flowering with gibberellic acid increase the time of germination, percentage and numbers of sprouts were reported by Ashwini (2019), Dhanasekaran et al., (2018), Rashmi and BhagwanDeen (2017) and Faraji and Basaki (2013) in gladiolus.

The various combinations of plant growth regulator and micronutrients are significantly influenced the plant height of the crop. The maximum plant height was measured in $\mathrm{GA}_{3}$ $200 \mathrm{ppm}(71.85$ and $70.38 \mathrm{~cm})$ during both the years 2017-18 and 2018-19.
However, maximum number of leaves per plant were recorded with the application of CCC $500 \mathrm{ppm}$ (8.40 and 8.88).The reduction in plant height with CCC (cycocel) application over control might be due to inhibitory role of plant growth regulators on cell division and cell elongation of apical merismatic cells and also at as anti-gibberellin synthesis (Cathey, 1961), Tak et al., (1999) observed that presoaking application of CCC in tuberose. Among micronutrients significantly highest plant height was recorded with the application of micronutrients $\mathrm{ZnSO}_{4} 0.5 \%+\mathrm{FeSO}_{4} 0.2 \%$ $(72.72$ and $71.23 \mathrm{~cm})$ during both the years. Maximum number of leaves (7.81 and 7.87) were recorded in $\mathrm{M}_{4}\left(\mathrm{ZnSO}_{4} 0.5 \%+\mathrm{FeSO}_{4}\right.$ $0.2 \%$ ) during both the years.

The plant height and number of leaves is increased by the combination of Zinc and Iron might be promoting due to the increased synthesis of auxin and utilization of carbohydrate in improving plant height. The findings discussed above are in conformity with reports made by Joshi et al., (2002) in desi rose, Halder et al., (2007) in gladiolus. The interaction effect of plant growth regulators and micronutrients for plant height and number of leaves per plant was found non-significant in both the years of experimentation.

Significantly minimum number of days taken to initiation of spike 94.08 days and 94.75 days were recorded with CCC $500 \mathrm{ppm}$ during the year 2017-18 and2018-19, respectively. The early flowering due to the application of CCC might be due to the fact that such plants have developed sufficient food reserve at initial stages. These reserved foods could have been utilized for the reproductive plant growth with restriction in vegetative plant growth, which was evident in the plants treated with cycocel. 
Table.1 Effect of Plant Growth Regulators and Micronutrients on Vegetative and Flowering Characters of Gladiolus (Gladiolus grandiflorus L.) cv. Novalux

\begin{tabular}{|c|c|c|c|c|c|c|c|c|c|c|c|c|}
\hline \multirow[t]{2}{*}{ Treatment } & \multicolumn{2}{|c|}{$\begin{array}{l}\text { Days to complete } \\
\text { sprouting }\end{array}$} & \multicolumn{2}{|c|}{$\begin{array}{c}\text { Height of plant at } 90 \\
\text { DAS }\end{array}$} & \multicolumn{2}{|c|}{$\begin{array}{l}\text { Number of leaves per } \\
\text { plant ( } 90 \text { days) }\end{array}$} & \multicolumn{2}{|c|}{$\begin{array}{c}\text { Days to initiation of } \\
\text { spike }\end{array}$} & \multicolumn{2}{|c|}{$\begin{array}{c}\text { Length of Spike } \\
\text { (cm) }\end{array}$} & \multicolumn{2}{|c|}{$\begin{array}{l}\text { Number of spikes } \\
\text { (Lack) per hectare }\end{array}$} \\
\hline & 2017-18 & 2018-19 & 2017-18 & 2018-19 & 2017-18 & 2018-19 & 2017-18 & 2018-19 & 2017-18 & 2018-19 & 2017-18 & 2018-19 \\
\hline $\mathbf{G}_{1}$ & 32.17 & 33.58 & 70.43 & 69.03 & 6.43 & 6.34 & 102.67 & 103.67 & 55.78 & 56.25 & 1.43 & 1.33 \\
\hline $\mathbf{G}_{2}$ & 30.17 & 31.25 & 71.85 & 70.38 & 7.42 & 7.06 & 97.75 & 100.08 & 61.60 & 62.77 & 1.53 & 1.43 \\
\hline $\mathbf{G}_{3}$ & 27.50 & 28.83 & 68.09 & 66.72 & 8.40 & 8.88 & 94.08 & 94.75 & 72.98 & 73.84 & 1.63 & 1.53 \\
\hline SEm \pm & 0.444 & 0.386 & 0.870 & 0.878 & 0.114 & 0.119 & 0.440 & 0.325 & 0.854 & 1.047 & 0.041 & 0.041 \\
\hline C.D. $(P=0.05)$ & 1.301 & 1.131 & 2.551 & 2.575 & 0.334 & 0.348 & 1.291 & 0.953 & 2.506 & 3.072 & 0.120 & 0.120 \\
\hline $\mathbf{M}_{1}$ & 29.89 & 30.89 & 67.76 & 66.39 & 6.97 & 6.93 & 99.44 & 100.69 & 60.50 & 61.50 & 1.40 & 1.30 \\
\hline $\mathbf{M}_{2}$ & 30.33 & 31.00 & 69.47 & 68.09 & 7.29 & 7.34 & 98.67 & 99.87 & 62.22 & 62.87 & 1.50 & 1.40 \\
\hline $\mathbf{M}_{3}$ & 29.44 & 31.78 & 70.54 & 69.12 & 7.60 & 7.56 & 97.56 & 99.11 & 65.01 & 65.46 & 1.57 & 1.47 \\
\hline $\mathbf{M}_{4}$ & 30.11 & 31.22 & 72.72 & 71.23 & 7.81 & 7.87 & 97.00 & 98.33 & 66.07 & 67.32 & 1.63 & 1.53 \\
\hline SEm \pm & 0.512 & 0.445 & 1.004 & 1.014 & 0.132 & 0.137 & 0.508 & 0.375 & 0.987 & 1.209 & 0.047 & 0.047 \\
\hline C.D. $(P=0.05)$ & NS & NS & 2.946 & 2.974 & 0.386 & 0.402 & 1.491 & 1.100 & 2.894 & 3.547 & 0.139 & 0.139 \\
\hline $\mathbf{G}_{1} \mathbf{M}_{1}$ & 31.67 & 33.33 & 67.77 & 66.40 & 6.13 & 5.93 & 104.33 & 105.00 & 50.93 & 51.47 & 1.30 & 1.20 \\
\hline $\mathbf{G}_{1} \mathbf{M}_{2}$ & 32.67 & 33.00 & 69.73 & 68.37 & 6.30 & 6.30 & 103.67 & 105.00 & 52.87 & 53.43 & 1.40 & 1.30 \\
\hline $\mathbf{G}_{1} \mathbf{M}_{3}$ & 31.67 & 34.00 & 71.23 & 69.80 & 6.57 & 6.40 & 101.67 & 102.67 & 59.30 & 59.23 & 1.47 & 1.37 \\
\hline $\mathbf{G}_{1} \mathbf{M}_{4}$ & 32.67 & 34.00 & 72.97 & 71.53 & 6.73 & 6.73 & 101.00 & 102.00 & 60.00 & 60.87 & 1.53 & 1.43 \\
\hline $\mathbf{G}_{2} \mathbf{M}_{1}$ & 30.00 & 30.00 & 69.10 & 67.77 & 6.67 & 6.63 & 98.33 & 102.00 & 60.20 & 61.80 & 1.40 & 1.30 \\
\hline $\mathbf{G}_{2} \mathbf{M}_{2}$ & 31.67 & 31.67 & 71.13 & 69.70 & 7.33 & 6.90 & 98.00 & 99.67 & 61.80 & 62.43 & 1.50 & 1.40 \\
\hline $\mathbf{G}_{2} \mathbf{M}_{3}$ & 29.00 & 31.67 & 72.67 & 71.20 & 7.70 & 7.23 & 97.67 & 100.00 & 62.03 & 62.67 & 1.57 & 1.47 \\
\hline $\mathbf{G}_{2} \mathbf{M}_{4}$ & 30.00 & 31.67 & 74.50 & 72.87 & 7.97 & 7.47 & 97.00 & 98.67 & 62.37 & 64.17 & 1.63 & 1.53 \\
\hline $\mathbf{G}_{3} \mathbf{M}_{1}$ & 28.00 & 29.33 & 66.40 & 65.00 & 8.10 & 8.23 & 95.67 & 95.07 & 70.37 & 71.23 & 1.50 & 1.40 \\
\hline $\mathbf{G}_{3} \mathbf{M}_{2}$ & 26.67 & 28.33 & 67.53 & 66.20 & 8.23 & 8.83 & 94.33 & 94.93 & 72.00 & 72.73 & 1.60 & 1.50 \\
\hline $\mathbf{G}_{3} \mathbf{M}_{3}$ & 27.67 & 29.67 & 67.73 & 66.37 & 8.53 & 9.03 & 93.33 & 94.67 & 73.70 & 74.47 & 1.67 & 1.57 \\
\hline $\mathbf{G}_{3} \mathbf{M}_{4}$ & 27.67 & 28.00 & 70.70 & 69.30 & 8.73 & 9.40 & 93.00 & 94.33 & 75.83 & 76.93 & 1.73 & 1.63 \\
\hline SEm \pm & 0.887 & 0.771 & 1.740 & 1.756 & 0.228 & 0.237 & 0.880 & 0.650 & 1.709 & 2.095 & 0.082 & 0.082 \\
\hline C.D. $(P=0.05)$ & NS & NS & NS & NS & NS & NS & NS & NS & 5.012 & 6.144 & NS & NS \\
\hline
\end{tabular}


Similar findings are reported by Lakshminarayana (2015) observed that CCC treated gladiolus corms came to flowering earlier because of the anti-gibberellins action of cycocel. A reduction in the level of endogenous gibberellins might be a prerequisite for flower induction that was achieved by pre-soaking of cycocel. Similar findings are reported by Kumar (2008) recorded pre-soaking of CCC minimized days to first flowering in gladiolus. Ganesh, (2013) reported the earlier flowering and opening of florets in tuberose. The number of days taken for spike initiation decreased significantly with foliar application of $\mathrm{ZnSO}_{4} 0.5 \%+$ $\mathrm{FeSO}_{4} \quad 0.2 \%$ (97.00 days in 2017-18 and 98.33 days in 2018-19, respectively). This reduction in number of days to spike initiation might be due to $\mathrm{Zn}$ and $\mathrm{Fe}$ because these micronutrients are quite effective in reducing the juvenile period of plants and favour to storage of more carbohydrates through photosynthesis, which might be the reason for earlier spike initiation. Similar findings are reported by Chattopadhayay et al., (2001) and Mir et al., (2007) in carnation. Interaction effect of growth regulators and micronutrients on number of days taken to spike initiation was found non-significant in both the years of experimentation. The combination of CCC 500 ppm with $\mathrm{ZnSO}_{4} 0.5 \%+\mathrm{FeSO}_{4} 0.2 \%$ showed earliest spike initiation (93.00 and 94.33 days in 2017-18 and 2018-19.

Significantly maximum length of spike (72.98 $\mathrm{cm}$ and $73.84 \mathrm{~cm}$ ) was recorded with the application of CCC 500 ppm during 2017-18 and 2018-19. The pre-soaking treatment of CCC $500 \mathrm{ppm}$ was proved effective for maximum length of spike. This might be due to the fact that reserve food material can be utilized for the productive purpose with restriction on vegetative plant growth due to gibberellin action of cycocel. The increase in number of spikes per plant and increase in yield spike per hectare might be due to the development of large number of spikes as the result of reproductive plant growth and maximum tillers of the plant. Also, the maximum number of leaves in this treatment had accumulated more carbohydrates through photosynthesis and was used for increasing the flower yield. These results are also similar with the finding of Bhattacharjee (1984), Kumar et al., (2008), Sudhakar and Kumar (2012) in the gladiolus. Among micronutrients significantly maximum length of spike $(66.07$ and $67.32 \mathrm{~cm})$ was found under $\left(\mathrm{ZnSO}_{4} 0.5 \%+\mathrm{FeSO}_{4} 0.2 \%\right)$ during 2017-18 and 2018-19. The differences in the response of micronutrients with respect to spike length might be due to the fact that these nutrients ( $\mathrm{Fe}$ and $\mathrm{Zn}$ ) activate several enzymes (catalase, peroxides, alcohol dehydrogenase, carbonic dehydrogenase, tryptophan synthetic, etc.) and involve them self in chlorophyll synthesis and various physiological activities by which plant growth and development are encouraged and the greater thickness of spike might be due to $\mathrm{Fe}$ and $\mathrm{Zn}$ because these micronutrients produce more food material which subsequently increased in the quality parameters, they also help in cell division and multiplication and enhance some physiological processes which are helpful to increase diameter of spike. Similar findings are also reported by Chopde et al., (2015) in gladiolus Dixit et al., (2008) in gladiolus and Ahmad et al., (2010) in rose. The interaction effect of growth regulator and micronutrients on length of spike was found significant in both the years of study. The maximum length of spike was recorded (75.83 and $76.93 \mathrm{~cm}$ during 2017-18 and 2018-19), respectively with combination of CCC 500 ppm with $\mathrm{ZnSO}_{4} 0.5 \%+\mathrm{FeSO}_{4}$ $0.2 \%$.

During both the years, number of spikes per hectare increased significantly with the application of CCC 500 ppm (1.63 lakh in 2017-18 and 1.53 lakh in 2018-19, 
respectively). This might be due to the fact that reserve food material can be utilized for the productive purpose with restriction on vegetative plant growth due to gibberellins action of cycocel. The increase in number of spikes per plant and increase in yield spike per hectare might be due to the development of large number of spikes as the result of reproductive plant growth and maximum tillers of the plant. Also, the maximum number of leaves in this treatment had accumulated more carbohydrates through photosynthesis and was used for increasing the flower yield. These results are in confirmity with the finding of Bhattacharjee (1984), Kumar et al., (2008), Sudhakar and Kumar (2012) in the gladiolus. Number of spikes per hectare (1.63 lakh in 2017-18 and 1.53 lakh in 2018-19) increased significantly with the application of micronutrient treatment $\left(\mathrm{M}_{4}\right) \mathrm{ZnSO}_{4} 0.5 \%+\mathrm{FeSO}_{4} 0.2 \%$ which was found at par with $\mathrm{M}_{3}$ and $\mathrm{M}_{2}$. The differences in the response of micronutrients with respect to spike length might be due to the fact that these nutrients (Fe and $\mathrm{Zn}$ ) activate several enzymes (catalase, peroxides, alcohol dehydrogenase, carbonic dehydrogenase, tryptophan synthetic, etc.) and involve them self in chlorophyll synthesis and various physiological activities by which plant growth and development are encouraged and the greater thickness of spike might be due to $\mathrm{Fe}$ and $\mathrm{Zn}$ because these micronutrients produce more food material which subsequently increased in the quality parameters, they also help in cell division and multiplication and enhance some physiological processes which are helpful to increase diameter of spike. Similar findings are reported by Chopde et al., (2015) and Dixit et al., (2008) in gladiolus. An Interaction effect of growth regulators and micronutrients for number of spikes per hectare was found non-significant during both the years of investigation.

\section{References}

Ashwini, A.; Munikrishnappa, P.M.; Kulkarni, Balaji, S.; Kumar, Rajiv; Amreen Taj and Kumar, Mohan S. (2019). Effect of plant growth regulators on vegetative and flowering parameters of gladiolus (Gladiolus hybridus L.) cv. Adigo Yellow. International Journal of Chemical Studies, 7(2): 1553-1556.

Bhattacharjee, S. K. (1984). The effects of growth regulating chemicals on Gladiolus. Garten bauwissenschaft, 49(3): 103-106.

Cathey, H. M. (1961). Comparative plant growth-retarding activity of Amo1618, Phosfon, and CCC. Botanical Gaz. 123: 51-57.

Chattopadhayay, M.K.; Das, T.K. and D.K. (2001). Effect of foliar application of zinc, copper and iron on yield and quality of Gladiolus grandiflorus cv. Mirela. Journal of Intracademicia, 5(3): 300-303.

Chopde, Neha; Gawali, R. P. and Seema, T. (2012). Evaluation of gladiolus varieties for flower and corm production under Vidarbha conditions. Plant Archives. 12: 911-91

Dhanasekaran, D.; Ramesh, Kumar S. and Sathappan C.T. (2018) Effect of plant growth regulators and biostimulants on growth and flowering of gladiolus (Gladiolus grandiflorus L.) cv. American Beauty, Journal of Ornamental Horticulture, 21(3): 95101.

Dixit, S.K.; Shyamal, M.M. and Kumar, S. (2008). effect of calcium sulphate, zinc sulphate and borax on flowering of gladiolus. Book of abstracts, National Symptoms Recent Advances in Floriculture, Navsari Agricultural University, Navsari, 6 March: 80.

Faraji, S. and Basaki, T. (2013). Evaluation of 
plant growth regulators on phonologic stages and morphological traits of Gladiolus (White prosperity cultivar). International Journal of Agronomy and Plant Production, 4(7): 15491551.

Ganesh, S.; Soorianathasundaram, K. and Kannan, M. (2013) Studies on effect of plant growth regulators and micronutrients on growth, floral characters and yield of tuberose (Polianthes tuberosa L.) cv. 'Prajwal'. Asian Journal of Horticulture,.8(2) pp.696-700 ref.15.

Halder, N.K.; Ahmed. R.; Sharifuzzaman. S.M.; Anzu-Man-Ara, Bagam and Siddiky, M.A. (2007). Boron and zinc fertilization on corm and cormel production of gladiolus terrace soils of Bangladesh. International journal of Sustain Crop Production.2(5): 85-89.

Joshi, Neelima and Raghav, Manoj (2002). Response of zinc sulphate on growth, yield and quality of potato, Journal of Indian Potato Association.33 (4): 244246.

Kumar P. Suresh; Bhagawati, R.; Kumar, Rajiv and Ronya T. (2008). Effect of plant growth regulators on vegetative growth, flowering and corm production of gladiolus in Arunachal Pradesh, Journal of Ornamental Horticulture: 11(4): 265-270,

Kumar, P. and Arora, J. S. (2000). Effects of Micronutrients on Gladiolus. Journal of Ornamental Horticulture (New Series), 3: 91-93.

Lakshminarayana, D. and Chandrasekhar, R. (2015).Studies on the influence of different practices, chemicals and plant growth regulators on dormancy, growth, flowering, corm production and postharvest vase life of gladiolus (gladiolus grandiflorus L.) cv. White Prosperity. College of Horticulture, Rajendranagar, Hyderabad - 30 Dr.
Y.S.R. Horticultural University, Ph.D thesis 2015-12-11,

Mir, M.A.; Singh, S. and Lone, R.A. (2007). Effect of $\mathrm{Zn}$ on the growth and flowering of Carnation (Dianthus caryophyllus L.) cv. Chabound Red. Asian Journal of Horticulture, 2(1): 147-148.

Panse, V. G. and Sukhatme, B. V. (1985). Statistical Method for Agricultural Workers, II ${ }^{\text {nd }}$. Ed., Indian Council of Agricultural Research, New Delhi.

Patel, J.; Patel, H. C.; Chavda, J. C. and Saiyad, M. Y. (2010). Effect of plant growth regulators on flowering and yield of gladiolus (Gladiolus grandiflorus L.) cv. American Beauty. Asian Journal of Horticulture, 5(2): 483-485.

Rashmi and BhagwanDeen (2017) Effect of Pre-Soaking of Corms in to Plant Growth Regulators on Growth and Flowering of Gladiolus (Gladiolus grandiflorus L.) cv. American Beauty, International Journal Current Microbiology Applied Sciences,6(12): 455-460

Sharma, J. R.; Gupta, R. B. and Panwar, R. D. (2004). Growth flowering and corm production in gladiolus cv Friendship as influenced by foliar application of nutrients and growth regulators, Journal of Ornamental Horticulture, 7(34): $154-158$.

Soni, S.S. and A.K. Godara. (2015). Effect of foliar application of borax, $\mathrm{FeSO}_{4}$ and $\mathrm{MnSO}_{4}$ on vegetative growth and flower production in gerbera. Environmental Life Sciences research sciences., 8(4): 581-584.

Sudhakar, M. and Kumar, S. Ramesh (2012) effect of growth regulators on growth, flowering and corm production of gladiolus (Gladiolus grandiflorusl.) Cv. White Friendship, Indian Journal of Plant Sciences, 1(23): 2319-3824. 
Swain, S. C. (2006) Effect of plant growth regulators on emergence of shoots and yield of corms and cormels in gladiolus. International Journal of Agricultural Sciences, 2(2) 438-440.

Tak, D.; Devendra, T. and Nagda, C.L. (1999). Effect of growth regulators on growth, flowering and yield of tuberose (Polianthes tuberosa L.) cv. Single. Scientific Horticulture, 6: 147150.

Tagliavini, Massimo and Rombola, Adamo Domenico (2001). Iron deficiency and chlorosis in orchard and vineyard ecosystems. European Journal of Agronomy 15(2): 71-92.

\section{How to cite this article:}

Abhinav Kumar and Arun Kumar Singh. 2020. Effect of Plant Growth Regulators and Micronutrients on Vegetative and Flowering Characters of Gladiolus (Gladiolus grandiflorus L.) cv. Novalux. Int.J.Curr.Microbiol.App.Sci. 9(11): 1136-1143. doi: https://doi.org/10.20546/ijcmas.2020.911.132 